\title{
CD Review: Tour de Force C Force
}

\author{
Diana Golden \\ Rutgers University ${ }^{1}$
}

\section{ABSTRACT}

Review of Tour de Force, the third album from C Force, an ensemble comprising flutist Christine Gangelhoff, euphoniumist Christian Justilien, and pianist Christy Lee. With repertoire spanning two centuries, the trio embarks on a musical tour of Guadeloupe, Jamaica, and Haiti on Disc One, with Trinidad and Tobago, Curaçao, the U.S. Virgin Islands and the Bahamas on Disc Two. Just as the eclectic album artwork by John Cox might suggest, Tour de Force provides listeners with a sense of the rich tapestry of musical connections in art music across the Caribbean. This two-disc set (released March 2016) was recorded at the Performing Arts Center of The College of The Bahamas and produced by Terry Manning of Lucky Seven Records.

As the premier flute, euphonium and piano trio of the Caribbean, C Force is unique not only for its instrumentation, but also for the ensemble's mission of promoting and raising awareness of art music traditions in The Bahamas and the Caribbean (LeGrand, 2014, p. IV-4). C Force performs local traditional music arrangements as well as original works. Though transcriptions of original works are sometimes regarded with suspicion by musicologists who prize "authenticity," C Force shows without a doubt that this music resonates well for the present. New works for the ensemble (some composed by Justilien) and existing Caribbean works discovered through Gangelhoff's extensive research, have greatly increased the repertoire available for this instrumentation and similar ensembles (LeGrand, 2014; Walters, 2014).

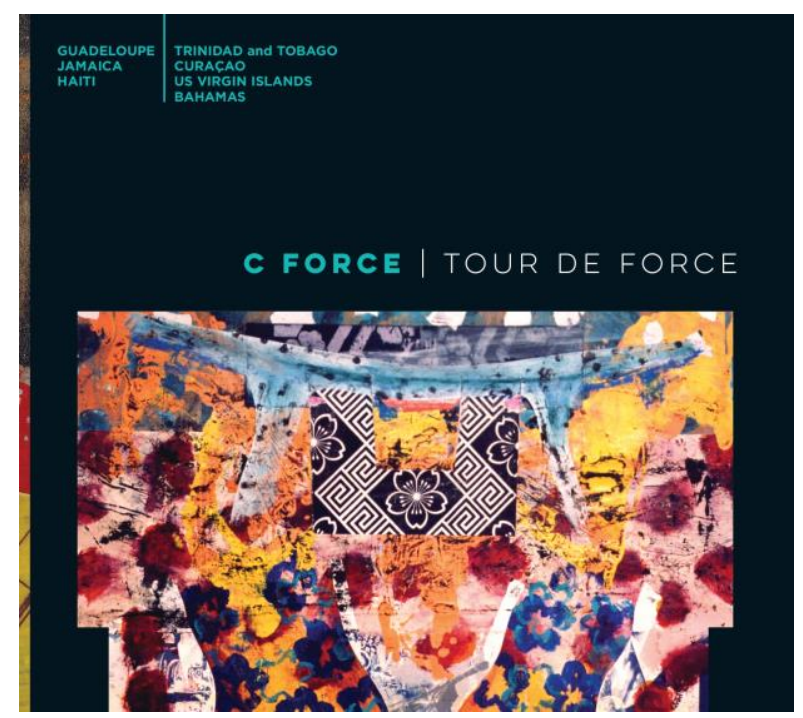

At the time Tour de Force was recorded, all members of $\mathrm{C}$ Force were full-time professors at The College of The Bahamas, fostering musical activity in the region and education for the next generation of Bahamian musicians (LeGrand, 2014, pp. IV-4, IV-6).

\footnotetext{
${ }^{1}$ Diana Golden, Doctoral candidate, Rutgers University, New Brunswick, New Jersey, USA.

E-mail: diana.golden@gmail.com

APA reference: Golden, D. (2016). CD review: Tour de Force: C Force. The International Journal of Bahamian Studies, 22, 85-90. http://dx.doi.org/10.15362/ijbs.v22i0.274
}

(c) D. Golden, 2016. Journal compilation @ The International Journal of Bahamian Studies, 2016 
The trio's educational initiatives do not end with their students, however. Gangelhoff worked with Ensemble du Monde and the Nassau Music Society to create and host the first International Symposium on Composers of African and Afro-Caribbean Descent in 2013 (Walters, 2014, p. 76). Additionally, Gangelhoff has co-authored a two-volume, comprehensive Caribbean art music bibliography with Cathleen LeGrand (2011; 2013).

C Force's evolution in mission and programming is reflected by the diverse range of musical output in three albums released since the ensemble's inception in 2008. The first CD, Tchaka Mizik (2010), highlights repertoire from Lee's experiences as a vocal coach and opera company pianist (LeGrand, 2014 , p. IV-6). ${ }^{2}$ In addition to an original composition by Justilien, the $\mathrm{CD}$ also features works by composers from Guadeloupe and Haiti (the publication of Gangelhoff and LeGrand's bibliography on Haitian art music followed shortly after Tchaka Mizik's release). In C Force's second album, Deep Blue (2013), the ensemble is situated musically - as well as geographically - in the Bahamas (Walters, 2014, p. 77). Justilien's "Bahama Islands Suite" and "Tilla" draw on Justilien's graduate research on Bahamian music and his performance in a variety of Bahamian musical genres (LeGrand, 2014, p. IV-5). Tour de Force, on the other hand, marks the ensemble's shift in focus and repertoire to the greater Caribbean (Zick, 2016).

In Joseph Bolougne's "Scena from Ernestine" (track 1) ${ }^{3}$, also known as the aria "O

2 Dr Christy Lee left the College of The Bahamas in 2014 and is now Lecturer in Collaborative Piano and Orchestra Conductor at Maryville College, Maryville, Tennessee.

3 There are variations in the spelling of the Chevalier de Saint-Georges's surname. Since the late 1970's however, the preferred spelling has been "Bologne," without the "u".
Clemangis, lis dans mon âme," Gangelhoff delivers a consistently beautiful tone, artfully presenting the vocal ornamentation with her own cadenza. While Lee offers a dramatic and stormy piano introduction to the piece, the majority of the track has a decidedly calm, matter-of-fact and more upbeat feel than some interpretations of this aria, even though Ernestine is separated from her lover Clemangis at this point in the opera (Hilliard, 2014). On the other hand, Gangelhoff and Lee's rendition may be aiming for an early classical style with more sparkle than suspense. More than evoking a grand operatic stage, "Scena from Ernestine" conveys the impression of an intimate flute sonata.

With her convincing musical phrasing, Christy Lee brings freshness and a sense of timelessness to Bolougne's "Adagio in F Minor for Piano" (track 2).

Oswald Russell's "Beachcomber" for solo flute (track 3) opens with a plaintively spoken melody. Questioning lines with large intervallic leaps eventually dissipate into melodic fragments. A contrasting, more contentious rhythmic section follows, peaking with a sarcastic flutter tongue, like a thumb on the nose. The piece ends much as it began: with uncertainty. Gangelhoff's playing skillfully differentiates characterizations of the energetic and lyrical to tell the story of "Beachcomber."

In "Elena and Her Variations" (track 4), originally for solo soprano recorder, Peter Ashbourne takes the theme from the traditional Jamaican folk song "Elena" and creates nine variations in styles ranging from Caribbean to etude, symphonic, chromatic, cloyingly classical, atonal, and fiddle-inspired. Gangelhoff's sense of articulation and syllabic emphasis make the folk song sound naturally crafted for solo flute.

It makes sense that the full ensemble of $\mathrm{C}$ Force would return to perform Werner 
Jaegerhuber's Chansons folkloriques d'Haït (tracks 5-10). ${ }^{4}$ There is plenty of historical precedent in Haiti for art music transcriptions for whichever instruments are available, as well as for art music performances by brass instruments in the fanfa-yo, or post-colonial military bands (Largey, 1994; Montès, 2003; Averill, 1994). Justilien and Gangelhoff both perform this work with a clear and open tone, without excess vibrato. Lee knows exactly when to feature the piano part and when to instead provide a colorful and textured accompaniment. Jaegerhuber's Chansons folkloriques d'Haïti are from a collection of folk melodies that Jaegerhuber recorded, transcribed, and then harmonized for voice and piano (Gangelhoff \& LeGrand, 2011, p. 30). The movements are based on prominent spirits from the Vodou religion, such as Erzulie, the spirit of love; Dambala, a serpent spirit and father figure; Ague, the spirit of water; Papa Simbi, spirit of the dead; and Marassa, child twin spirits representing abundance.

In "Erzulie malade," the euphonium begins the folk melody of Erzulie in 2/4, then as the song transitions to minor for the spirit's lament, the flute performs in a syncopated $5 / 8$. Jaegerhuber argued that the 5/8 meter was most accurate for notating African rhythms and melodies in Vodou music (Largey, 1991; 2004). Syncopation within the $5 / 8$ meter is known as distinctly Haitian in style due to this performance practice within the méringue, a national symbol of Haiti (Largey, 1991; Gray \& Gerstin, 2010).

"M'ague Ta Royo," "Invocation a Dambala," and "Erzulie Oh" use atmospheric percussion to enhance a simple melody passed and shared by the trio. At times in these movements, the flute and euphonium slip into a fantasia-like recitative as the piano holds a low chord or

4 Track numbers of disc and digital versions may vary. trill resembling a drum roll. This is consistent with Jaegerhuber's original transcriptions for voice and piano, in which Jaegerhuber wrote additional Haitian tanbou (drum) parts for 19 of 35 melodies (Procopio, 2005). For folk songs with no additional drum part, Jaegerhuber included references to the drum in the piano part with a technique called tanbou kache (hidden drum), in which the listener hears a drum even when it is not in the score (Largey, 2006; Procopio, 2009).

"Gros Loa Moin" presents transnational connections and a cosmopolitan outlook to Jaegerhuber's composition, as the title recalls an African-American concert spiritual "Great Spir't O' Mine". Like "Erzulie malade," "Gros Loa Moin" is in 5/8 meter (Largey, 2006).

"Marassa e lou," a song about twin spirits of blessings and strength, follows the previous movements of lament to end Chansons folkloriques d'Haïti on a hopeful note. In this and the other Haitian folk songs, C Force captures a sense of the expansive and majestic character of each spirit deity.

While Jaegerhuber emphasizes melody, the most distinctive feature of Julio Racine's compositions is rhythm (Procopio, 2005, p. 103). In Racine's Vodoo Jazz Sonata for Flute and Piano (tracks 11-13), he uses rhythms from music and dance in traditional Vodou ceremonies (Procopio, 2005). But like many Haitian composers who were part of the diaspora and seeking to relate to international audiences, Racine also incorporates in his music a wide range of styles from jazz and European influences (Largey, 1991, pp. 198199; Largey, 2006, p. 18; Procopio, 2009, p. 72). Since members of $C$ Force regularly perform in a number of styles (Gangelhoff, personal communication, March 30, 2016), Gangelhoff and Lee exhibit flair and ease in their performance of Racine's Vodoo Jazz Sonata, especially in the jubilant third movement, "Avec allure" (track 13). In the 
second movement "Priè" (track 12), Gangelhoff and Lee respond to Racine's soulful prayer with genuine emotional depth. Both the piece and performance of Vodoo Jazz Sonata are at once unique and universally appealing.

In "Nibo" (track 14), Ludovic Lamothe's catchy tune sounds as though it was taken from today's Caribbean popular music, though it was first performed in 1934, when the work won the competition for the best méringue in the 1934 Haitian Carnival (Gangelhoff and LeGrand, 2011, p. 25; Averill, 1994, p. 222; Zick, n.d.). In fact, Rara bands of the Haitian Carnival often include similar instrumentation to C Force: flute, tanbou drum, tambourine, vaksin bamboo trumpet and other brass instruments (Averill, 1994, pp. 220-222). In Tour de Force's version, the flute and euphonium perform the melody and harmony while the piano part fills out the chords and covers the méringue and responsorial rhythms. Additional Caribbean percussion instruments have been added to the track in later verses. Musical protest as a form of political resistance has always been popular in Haiti, and the publication of "Nibo" towards the end of the US Occupation was no exception to this (Dirksen, 2012, pp. 111123; Averill, 1994, pp. 217, 220-222). Protesters adapted their own words to the melody, since "Nibo" has no text (Gangelhoff \& LeGrand, 2011, p. 25).

"Williams" Waltz" (track 15) by Atiba Williams defies expectations in its orchestration. First, Justilien plays a lighthearted, playful opening theme, which contrasts with Gangelhoff's sung echo of the melody. The melody is passed to the piano and harmonized by the euphonium as the flute accompanies the two instruments in offbeats. The theme returns to the euphonium until the end of "Williams' Waltz," where the trio joins forces triumphantly.
Statius Miller's Three Waltzes for Solo Piano are compelling for their rhythmic density. Lee plays "Tristeza, op. 2, No. 12," "Nostalgia, op. 2, No. 22," and "Despedida, op. 4, No. 25 " (tracks 16-18) with the passion of a tango and the rubato of a romance. While the right hand plays the most obvious melody, the harmonic structure from downbeats in the left hand also carries a melodic line.

As Gangelhoff and LeGrand (2011) explain in their bibliography, Alton Adams' "Warbling in the Moonlight" for piccolo and band/piano accompaniment (track 19) uses the binary structure of quelbe, a traditional style of popular music with African and European roots, as well as the official music of the Virgin Islands (p. 54). Gangelhoff plays with virtuosity, warmth, and resonance even in upper registers of the piccolo.

The Puerto Rican-derived "Danza" (track 20) is by composer Raymond La Motta, also from the U.S. Virgin Islands. Lee opens the work with a grand flourish. Justilien's stylized slides and blue notes give the "Danza" a sung-as well as danced-quality. Gangelhoff achieves the same effect through her timing and varied vibrato. The flute and euphonium dance together for the final iteration of the tune.

The Bahama Islands Suite (tracks 21-25) is Justilien's fun, danceable, and heartwarming musical tribute to his homeland. Each movement recalls a different part of the Bahamas. "San Salvador" (track 21) muses on the island's relationship with Spain (Lee, 2013). As one might expect, Justilien's writing allows the euphonium to shine in idiomatic melodic lines, especially in "Grand Bahama (Pinder's Point)" (track 22). The piano often takes an accompanimental and rhythmic role, while the flute and euphonium share melodic material. In the meditative "Eleuthera (Da Bight)" (track 23), rolled piano chords and a simple melody in the flute 
and euphonium are accompanied by recorded ocean waves. In "Ragged Island (Deep South)" (track 24), the "beauty and serenity" of the island is haunted by an eerie melody in the flute (Lee, 2013). According to the liner notes for Deep Blue, "Ragged Island" portrays the beauty of the island as well as the 1980 bombing of four marines by Cuban pilots. In the final movement of the Bahama Islands Suite, "Bimini (Blue Marlin)" (track 25), the euphonium plays what sound like hunting calls, with the flute answering in trills. The clue to the significance of calls from the euphonium lies in the companion poetry created for the Bahama Islands Suite by poet Marion Bethel. The poet shares the story of Justilien's calling, in depicting the "new anthems of Guanahani/score a classical suite: written in sugar cane fingers/of a young boy/and blown into the lungs/of a silver euphonium" (Lee, 2013).

Lucas Manning's adaptation of 'Pinder's Point" as a house remix with techno beats (track 26) shows the versatility of the Bahama Islands Suite.

Tour de Force recognizes and showcases the long history of art music composition and performance in the Caribbean. With works deriving from classical, folk, and popular sources, C Force's programming on Tour de Force reflects the many musical influences passing through the Caribbean. Tour de Force documents an important moment in the recognition of Caribbean art music.

\section{REFERENCES}

Averill, G. (1994). Anraje to Angaje: Carnival politics and music in Haiti.

Ethnomusicology: Journal of the Society for Ethnomusicology, 38(2), 217-247.

Retrieved from http://www.jstor.org/stable/851739

Dirksen, R. (2012). Power and potential in contemporary Haitian music: Mizik angaje, cultural action and community-led development in pre-and post-quake Portau-Prince. (Doctoral dissertation, University of California, Los Angeles). Retrieved from http://escholarship.org/uc/item/0hn8f07g

Gangelhoff, C., \& LeGrand, C. (2011). Art music by Caribbean composers. International Journal of Bahamian Studies, 17(1), 1-59. Retrieved from http://journals.sfu.ca/cob/index.php/files/is sue/view/30

Gangelhoff, C., \& LeGrand, C. (2013). Art music by Caribbean composers. The
International Journal of Bahamian

Studies, 19(2), 1-76. Retrieved from http://journals.sfu.ca/cob/index.php/files/is sue/view/32

Gray, J., \& Gerstin, J. (2010). From Vodou to Zouk: A bibliographic guide to muisc of the French-speaking Caribbean and its diaspora. Nyack, NY: African Diaspora Press.

Hilliard, R.-M. (2014, February). Joseph Boulogne. Retrieved from http://www.raemyra.com/joseph-boulogne/

Largey, M. (2004). Ethnographic transcription and music ideology in Haiti: The music of Werner A. Jaegerhuber. Latin American Music Review 25(1), 1-31. Retrieved from http://www.jstor.org/stable/3598699

Largey, M. (2006). Vodou nation: Haitian art music and cultural nationalism. Chicago, IL: University of Chicago Press.

Largey, M. (1994). Composing a Haitian cultural identity: Haitian elites, African ancestry, and musical discourse. Black 
Music Research Journal 14(2), 99-117.

Retrieved from

http://www.jstor.org/stable/779479

Largey, M. (1991). Musical ethnography in

Haiti: A study of elite hegemony and musical composition. (Doctoral dissertation, University of Indiana). Available from ProQuest database.

Lee, C. (2013). Liner notes, "Bimini (Blue Marlin)," from Deep Blue, C Force. Lucky Seven Records, B00GRKVA1A.

LeGrand, C. (2014). "The isle is full of noises": C Force and musical life in The Bahamas. The International Journal of Bahamian Studies, 20(2), IV 4-8. http://dx.doi.org/10.15362/ijbs.v20i2.214

Montès, J. (2003). An annotated translation thesis of Constantin Eugene Moïse Dumervé's Histoire de la musique en Haïti $=$ The history of music in Haiti. (Doctoral dissertation). University of Iowa. (UMI\# 3097601)

Procopio, M. J. (2005). Haitian classical music, vodou, and cultural identity: An examination of the classical flute compositions by Haitian composer Werner
A. Jaegerhuber. (Doctoral dissertation). Michigan State University. (UMI\# 3171512)

Procopio, M. J. (2009). Challenging cultural ambivalence in Haiti and the Haitian diaspora through vodou-inspired music, education and humano-centrism. (Master's thesis). Michigan State University. (UMI\# 1478826)

Walters, A. (2014). CD Review: Deep Blue; C Force. International Journal of Bahamian Studies, 20(1), 76-78. http://dx.doi.org/10.15362/ijbs.v20i1.223

Zick, W. (2016, March 17). The trio C Force issues its third recording, "Tour-de-Force," A vibrant 2-disc survey of classical music of the Bahamas and the Caribbean region. [Web blog post]. Retrieved from http://www.africlassical.blogspot.com/201 6/03/the-trio-c-force-issues-its-third.html

Zick, W. (n.d.). Ludovic Lamothe (18821953). Retrieved from http://www.chevalierdesaintgeorges.homes tead.com/lamothe.html 